\title{
Phylogeny and cultivation of the holocarpic oomycete Diatomophthora perforans comb. nov., an endoparasitoid of marine diatoms
}

\author{
Anthony T. Buaya ${ }^{1,2} \cdot$ Sebastian Ploch $^{2} \cdot$ Alexandra Kraberg $^{3} \cdot$ Marco Thines $^{1,2}$ (D)
}

Received: 27 November 2019 / Revised: 13 February 2020 / Accepted: 14 February 2020

(C) The Author(s) 2020

\begin{abstract}
Oomycetes infecting diatoms are biotrophic parasitoids and live in both marine and freshwater environments. They are ubiquitous, but the taxonomic affinity of many species remains unclear and the majority of them have not been studied for their molecular phylogeny. Only recently, the phylogenetic and taxonomic placement of some diatom-infecting, early-diverging oomycetes was resolved, including the genera Ectrogella, Miracula, Olpidiopsis, and Pontisma. A group of holocarpic diatom parasitoids with zoospores swarming within the sporangium before release were found to be unrelated to the known genera with diatom-infecting species, and were re-classified to a new genus, Diatomophthora. However, about a dozen species of holocarpic diatom parasitoids with unclear affinity remained unsequenced, which includes a commonly occurring species so far identified as Ectrogella perforans. However, this assignment to Ectrogella is doubtful, as the species was not reported to feature a clear-cut diplanetism, a hallmark of Ectrogella s. str. and the whole class Saprolegniomycetes. It was the aim of the current study to clarify the phylogenetic affinities of the species and if the rather broad host range reported is correct or a reflection of cryptic species. By targeted screening, the parasitoid was rediscovered from Helgoland Roads, North Sea and Oslo Fjord, Southern Norway and investigated for its phylogenetic placement using small ribosomal subunit (18S) sequences. Stages of its life cycle on different marine diatoms were described and its phylogenetic placement in the genus Diatomophthora revealed. A stable host-parasite axenic culture from single spore strains of the parasitoid were established on several strains of Pleurosigma intermedium and Coscinodiscus concinnus. These have been continuously cultivated along with their hosts for more than 2 years, and cultural characteristics are reported. Cross-infection trials revealed the transferability of the strains between hosts under laboratory conditions, despite some genetic distance between the pathogen strains. Thus, we hypothesise that $D$. perforans might be in the process of active radiation to new host species.
\end{abstract}

Keywords Diatomophthora $\cdot$ Ectrogella $\cdot$ Olpidiopsis $\cdot$ Oomycetes $\cdot$ Phylogeny

\section{Introduction}

Oomycete parasitoids of diatoms are ubiquitous in the aquatic environment (Karling 1942; Sparrow 1960). Despite their

Section Editor: Marc Stadler

Marco Thines

m.thines@thines-lab.eu

1 Department of Biological Sciences, Institute of Ecology, Evolution and Diversity, Goethe-Universität Frankfurt am Main, Max-von-Laue Str. 13, 60438 Frankfurt am Main, Germany

2 Senckenberg Biodiversity and Climate Research Center, Senckenberganlage 25, 60325 Frankfurt am Main, Germany

3 Alfred Wegener Institute Helmholtz Centre for Polar and Marine Research, Am Handelshafen 12, 27570 Bremerhaven, Germany widespread occurrence (Garvetto et al. 2018; Hassett et al. 2019), little is known about the biology and ecology of these holocarpic organisms, especially in marine habitats (Sparrow 1936; Scholz et al. 2015; Hassett et al. 2019). However, these parasitoids are known to play a significant role in breaking down blooms of their host diatoms, and might also play a role in the marine food web (Skovgaard 2014; Scholz et al. 2015). So far, only three marine oomycetes-infecting diatoms (Lagenisma coscinodisci, Diatomophthora drebesii and Miracula helgolandica) have been classified and studied for molecular phylogeny (Thines et al. 2015; Buaya et al. 2017), but additional lineages have been identified that have not been formally described (Badis et al. 2019; Garvetto et al. 2018, 2020). The Coscinodiscophyceae parasitoid L. coscinodisci was found to belong to the basal Saprolegniomycetes (Thines et al. 2015). Miracula helgolandica was inferred to 
be the earliest-diverging oomycete lineage together with the recently described freshwater parasitoid $M$. moenusica, while $D$. drebesii formed a monophyletic group together with D. gillii and uncultured environmental sequences (Buaya and Thines 2019; Buaya et al. 2017; 2019a). Only recently, phylogenetic affinities of the genus Olpidiopsis and Ectrogella were resolved and their type species epitypified, leading to the taxonomic revisions of these two important taxa of early-diverging oomycetes (Buaya et al. 2019c; Buaya and Thines 2020). The genus Olpidiopsis with its type species $O$. saprolegniae was found to be unrelated to the parasites of red algae and diatoms parasitoids (Buaya et al. 2019c). Even though monophyly of the parasites of red algae was not resolved in Badis et al. 2019, a monophyletic grouping was observed in Buaya et al. (2019c) and Buaya and Thines (2020). Interestingly, the genus Ectrogella with its type species $E$. bacillariacearum, which was previously speculated to belong to the early-diverging lineages, was found to be embedded in the basal Saprolegniomycetes (Buaya and Thines 2020) and epitypified with a specimen exhibiting the typical thallus and exit-pore morphology described for the species by Zopf (1884). Consequently, the olpidiopsis-like (i.e. those holocarpic oomycetes with simple thalli and zoospores that start swarming within the mature thallus) diatom parasitoids were assigned to a new genus, Diatomophthora, while the parasites of red algae were re-classified to the order Pontismales (Buaya et al. 2019c; Buaya and Thines 2020), following the classification first suggested by Dick (2001).

Several marine oomycete-infecting diatoms have not been rediscovered and studied for molecular phylogeny, including Ectrogella licmophorae, E. perforans and E. eurychasmoides, as well as a Petersenia sp., which was only partially described in Rhizosolenia (Petersen 1905; Scherffel 1925; Feldmann and Feldmann 1955; Johnson 1967). Of these oomycetes, E. perforans is probably the most frequently reported one and has been observed during blooms of various diatom genera, e.g. Licmophora, Striatella, Podocystis, and Thalassionema (Petersen 1905; Sparrow 1960). As currently circumscribed (Sparrow 1960), E. perforans is a plurivorous parasitoid of various pennate diatoms Licmophora (L. abbreviata, L. lyngbyei, L. flagellata, and L. gracilis), Striatella (S. unipunctata), Podocystis (P. adriatica), Thalassionema (T. nitzschioides), Lauderia (L. borealis), and Synedra (S. ulna, S. tabulata). The parasitoid usually has multiple broadly conical discharge tubes, a characteristic similar to several Ectrogella species (Petersen 1905; Sparrow 1960). However, its phylogenetic placement in Ectrogella remains uncertain in the light of a recent study that demonstrated that the type species of Ectrogella is a member of an early diverging group of the Saprolegniomycetes (Buaya and Thines 2020). Buaya and Thines (2020) have shown that E. bacillariacearum, which has a clearly defined diplanetism belongs to the Saprolegniomycetes that are characterised by this. In contrast, two parasitoids without clear-cut diplanetism belonged to the early-diverging oomycetes and were, thus, classified in the new genus Diatomophthora (Buaya and Thines 2020). While the absence of a clear-cut diplanetism does not prove that a secondary spore type is entirely absent, it highlights that spore cysts do not give rise to secondary zoospores with a different anatomy within a few hours, which is a hallmark of the Saprolegniomycetes, such as Achlya and Saprolegnia (Johnson 1967; Beakes and Thines 2017). Ectrogella perforans does not have a clear-cut diplanetism (Sparrow 1960; Johnson 1966; Raghukumar 1978, 1980b; Dick 2001), which hints to the possibility that it might not be a member of the genus Ectrogella. The parasitoid was also often synonymized with E. licmophorae, and to lesser extent E. eurychasmoides because of its host range similarities (Dick 2001), despite differences in spore formation. While screening for diatom parasitoids from marine phytoplankton and coastal sediment samples from Helgoland Roads, Helgoland Island in North Sea, and Oslo Fjord, Southern Norway during autumn and winter of 2017, parasitoids with features of E. perforans were found sporadically in various marine diatoms (Coscinodiscus concinnus, C. granii, C. wailesii, Pleurosigma intermedium, Licmophora abbreviata, and Synedra ulna). It was the aim of this study to establish dual culture for the Coscinodiscus- and the Pleurosigma-infecting strains as well as to obtain sequence data from these strains and similar parasitoids of other diatoms to clarify the potential host range and phylogenetic relationships of E. perforans.

\section{Materials and methods}

\section{Sampling, isolation and characterisation}

Diatom samples were collected from the low littoral zone in Oslo Fjord, Drobak, Southern Norway (59 $39^{\circ} 31^{\prime \prime} \mathrm{N} 10^{\circ} 37^{\prime}$ 47" E), and at Helgoland Roads located between Helgoland Island and Düne Island, North Sea, Germany (54 $10^{\prime} 54^{\prime \prime} \mathrm{N}$ $7^{\circ} 53^{\prime} 52^{\prime \prime} \mathrm{E}$ ), as described previously by Kristiansen et al. (2001) and Kraberg et al. (2015), respectively. Licmophora abbreviata and S. ulna infected with oomycetes from Norway were collected in September 2017, by plucking algae from their substrates and immersing them in fresh seawater using plastic bottles. Subsequently, algal segments with biofilms of epiphytic diatoms were transferred to several 15-mL Petri dishes containing seawater and immediately screened for oomycete-infected diatoms, using a compound inverted light microscope. Infected diatoms were carefully detached from their algal substrates using a $10-\mu \mathrm{L}$ micropipette tip, rinsed multiple times in autoclaved seawater and then immersed in $2-\mathrm{mL}$ vials containing a $0.5 \mathrm{~mL}$ RNAlater (Invitrogen, Thermo Fisher, Lithuania) or $70 \%$ ethanol 
(VWR, France) for subsequent DNA extraction. Approximately 20 infected cells of $L$. abbreviata and 50 infected cells of $S$. ulna were collected this way for DNA extraction. Coscinodiscus concinnus, C. wailesii, C. granii and $P$. intermedium infected with oomycetes from Germany were collected in December 2017, using 80- $\mu \mathrm{m}$ and 20- $\mathrm{mm}$ mesh plankton nets (Hydro-Bios, Kiel, Germany), horizontally towed at 1-2 $\mathrm{m}$ depth. About $10 \mathrm{~mL}$ of the fresh plankton concentrates was poured into several $15-\mathrm{mL}$ petri dishes and screened for oomycete-infected diatoms using an inverted compound light microscope (Type AE31, Motic, Xiamen). Infected diatoms were picked individually using a $10-\mu \mathrm{L}$ micropipette (Brandt, Germany), rinsed multiple times in autoclaved seawater and transferred to sterile seawater for axenic cultivation or in $2-\mathrm{mL}$ vials containing a $0.5 \mathrm{~mL}$ RNAlater solution for DNA extraction. Approximately 100 infected cells of $C$. concinnus and 100 infected cells of $P$. intermedium were collected for DNA extraction from raw cultures of the net plankton and established co-cultures. Samples preserved in $70 \%$ ethanol were deposited in the herbarium collection of the Senckenberg Museum of Natural History (FR), Cryptogams Section, Frankfurt am Main (accession: L. cf. abbreviata (sample A) FR-0046124, L. cf. abbreviata (sample B) FR-0046125, S. ulna FR-0046120, C. concinnus (sample A) FR-0046118, C. concinnus (sample B) FR-0046119, P. intermedium FR-0046117). Morphological characterisation of the parasite was made as described earlier (Buaya et al. 2019b) using a compound light microscope (Imager2, Carl Zeiss Göttingen, Germany) with DIC, and photographs were taken using Zeiss Axiocam MRc5 (Carl Zeiss, Göttingen, Germany). In addition, cellulose presence in the thallus wall of the parasitoids was tested using a solution of zinc iodine (Carl Roth $\mathrm{GmbH}$, Germany). The identity of the host diatoms was determined either by light microscopy or $18 \mathrm{~S}$ sequence barcoding as outlined for the oomycetes below.

\section{Cultivation and cross-infection experiments}

Uninfected $P$. intermedium and $C$. concinnus were isolated for the establishment of host and parasite dual culture using Guillard's f/2 (Sigma-Aldrich, UK) marine water enrichment medium (Guillard and Ryther 1962; Schnepf and Drebes 1977). Cultivation was done in a climate chamber (Conviron, CMP 6010, Canada) at $16{ }^{\circ} \mathrm{C}$ and $12{ }^{\circ} \mathrm{C}$, for $14 \mathrm{~h}$ and $10 \mathrm{~h}$, respectively, cycle program with $18 \mu \mathrm{M} /$ $\left(\mathrm{sm}^{2}\right)$ at the 14-h lighting period (Narva, bio-vital, Germany) in 9-cm petri dishes (Sarstedt, Nümbrecht, Germany). Serial sub-culturing procedures for achieving pure cultures were performed as described previously by Buaya et al. (2019c). Once a week, four infected diatoms containing a single parasite thallus were inoculated into healthy 2 -week-old cultures of $P$. intermedium and 1-week-old cultures of $C$. concinnus, to maintain the cultures. The inoculum of each parasite originated from a single thallus of an infected $C$. concinnus and a $P$. intermedium cell, and the absence of microbial contaminants was confirmed by careful microscopic examination.

In order to clarify the host specificity of the closely related parasites, cross-infection trials of the two oomycetes infecting $P$. intermedium and $C$. concinnus were conducted. Licmophora abbreviata and $S$. ulna could not be included in the experiment because attempts to establish a culture of these diatoms in several marine enrichment media (e.g. Guillard's f/ 2 medium, W.C. medium, D.A.M. medium) failed and, thus, also no cultures of their parasitoids could be established. For host specificity testing, 2-5 thalli of the oomycete infecting C. concinnus were inoculated into each of the three single cell strains established of $P$. intermedium (PL1, PL2, PL3). Similarly, 2-5 thalli of oomycete-infected $P$. intermedium were inoculated into each of the three $C$. concinnus culture single cell strains (CC1, CC2, CC3) established. Cultures were then incubated as described above and were observed for infection daily for up to 10 days using a compound inverted light microscope.

All cultures are available from the authors upon request, as no repository we have asked would accept obligate biotrophic pathogens that require frequent transfer.

\section{DNA extraction, PCR amplification and phylogenetic analyses}

DNA extraction of the oomycetes infecting $L$. abbreviata, S. ulna, C. concinnus, and P. intermedium was performed using an innuPREP Plant DNA extraction Kit (Analytik Jena, Germany), as previously described (Thines et al. 2015). Initially, isolates were centrifuged at $19000 \mathrm{~g}$ for $120 \mathrm{~s}$ at $22{ }^{\circ} \mathrm{C}$ to pellet the cells. Subsequently, RNAlater or $70 \%$ ethanol was removed and $400 \mu \mathrm{L}$ SLS buffer from the extraction kit was added. About $100 \mathrm{mg}$ of sterile $0.1 \mathrm{~mm}$ Silica Glass Beads (Carl Roth GmbH, Germany) were added into each 2-mL tubes (Sarstedt, Germany) and homogenised at maximum frequency $(25 \mathrm{~Hz})$ for $25 \mathrm{~min}$ in Retsch Mixer Mill MM 200 (Retsch GmbH, Germany). The PCR amplification of the nuclear encoding small subunit (nrSSU) was performed as described in Buaya et al. (2019b) using Mango-Taq DNA Polymerase (Bioline, UK) but with the primer pair EUK422-445 and EUK1422-1440_R (Wang et al. 2014). Positive amplicons were sent for sequencing to the laboratory centre of the Senckenberg Biodiversity and Climate Research Centre, Frankfurt am Main (SBiK-F, Frankfurt, Germany) using the $18 \mathrm{~S}$ primer pairs EUK422445 and EUK1422-1440_R (Wang et al. 2014), which were also used in the PCR. In addition, direct PCRs were also done as described in Buaya et al. (2019a) for extracted DNA. Due to the small amount of starting material and the many PCR cycles therefore performed, PCR reactions had a larger 
amount of primer dimers and background amplification. To obtain better nrSSU sequencing results of the oomycetes infecting L. abbreviata and S. ulna, PCR amplicons were cloned. Initially, the PCR amplicons were purified using magnetic bead-based nucleic acid purification (AMPure XP, Beckman Coulter Inc., USA). Subsequently, PCR amplicons were diluted by a factor of ten, and the mixture was cloned into competent Escherichia coli using a StrataClone TA cloning kit (Agilent Technologies, Santa Clara, USA) following instructions of the manufacturer, and as described previously in Buaya et al. (2017). Single bacterial colonies were picked into a $20-\mu \mathrm{L}$ molecular grade water, and colony PCR was carried out with the Mango DNA Polymerase using M13-F and M13-R plasmid primers with amplification conditions set to an initial denaturation at $96{ }^{\circ} \mathrm{C}$ for $10 \mathrm{~min}, 36$ cycles at $96{ }^{\circ} \mathrm{C}$ for $20 \mathrm{~s}, 56{ }^{\circ} \mathrm{C}$ for $20 \mathrm{~s}$ and $72{ }^{\circ} \mathrm{C}$ for $60 \mathrm{~s}$, and concluding with a final elongation at $72{ }^{\circ} \mathrm{C}$ for $10 \mathrm{~min}$. Positive clones were sent for sequencing to the laboratory centre of the Senckenberg Biodiversity and Climate Research Centre (Frankfurt am Main, Germany) using M13 (M13-F, M13-R), $\mathrm{T} 3$, and $\mathrm{T} 7$ plasmid primers. The resulting sequences were prepared using Geneious (version 5.6), and the assembled sequences of the oomycetes infecting L. abbreviata, S. ulna, $C$. concinnus and $P$. intermedium were added to the dataset of Buaya and Thines (2020), to which also additional sequences from Garvetto et al. 2018, 2020) were added, aligned using muscle (Edgar 2004) as implemented in MEGA5 (Tamura et al. 2011), with a gap opening penalty of 600 and a gap extension penalty of 6 . Phylogenetic analyses were done using MEGA5 for Minimum Evolution analysis with 1000 bootstrap replicates, and on the TrEase webserver (http://thineslab.senckenberg.de/trease/), using RAxML (Stamatakis 2014) for Maximum Likelihood inference, also with 1000 bootstrap replicates. Bayesian inference was done on the same webserver, which implements MrBayes, version 3.2 (Ronquist et al. 2012), running 10 million generations and discarding the first 3 million generations. Subsequently, every 10.000 th tree was sample for calculating posterior probabilities. The partial $18 \mathrm{~S}$ (nrSSU) sequences obtained in this study were deposited in GenBank (L. cf. abbreviata (sample A) MN764292, L. cf. abbreviata (sample B) MN764290, S. ulna MN764298, C. concinnus (sample A) MN764256, $C$. concinnus (sample B) MN764245, P. intermedium MN764291).

\section{Results}

\section{Parasite detection, culture establishment}

In this study, oomycete parasitoids were isolated from multiple marine diatoms: L. abbreviata, S. ulna, C. concinnus, C. wailesii, C. granii and P. intermedium, collected in late autumn of 2017 from Oslo Fjord in Southern Norway, and in winter of 2017 from Helgoland Roads, near Helgoland island in the North Sea, Germany. The majority of screened L. abbreviata and S. ulna from Oslo Fjord, as well as of $P$. intermedium from Helgoland Roads and about a third of Coscinodiscus (C. concinnus, $C$. wailesii, $C$. granii) from the latter region were infected by parasitoids. Infections were also observed in the epiphytic diatoms Achnanthes longipes, Striatella unipunctata, Thalassionema nitzschioides and Fragilaria sp. from Norwegian samples at low frequency, but as no high-quality sequences could be obtained from these isolates, they were excluded from the phylogenetic analyses. Frequently, biofilms of epiphytic diatoms sampled (e.g. L. abbreviata, S. ulna and S. unipunctata) (Figs. 1d, 2d) were attached to red algae and green algae, especially Ceramium rubrum, which was also heavily infected by Pontisma lagenidioides, as reported by Buaya et al. (2019c). Diatoms samples from Helgoland Roads were also observed to be infected by oomycetes and protists, such as $L$. coscinodisci (Drebes 1968) on Coscinodiscus (C. granii, C. wailesii) and Phagomyxa odontellae (Schnepf et al. 2000) on Odontella sinensis. Establishment of a stable host and parasite dual culture of all oomycete parasitoids was attempted using Guillard's f/2 enrichment medium; however, only the diatom Coscinodiscus (C. concinnus, C. wailesii, C. granii) and P. intermedium together with their parasitoid were successfully cultivated and maintained in long term by periodic serial sub-culturing on diurnal cycle incubation. After prolonged serial culturing transfers of the host and parasite culture, C. wailesii (CW1, CW2, CW3) and C. granii (CG1, CG2, CG3) strains gradually became resistant to the infection after undergoing sexual cycles. Only C. concinnus (CC1, CC2, CC3) and P. intermedium (PL1, PL2, PL3) strains remained susceptible to the parasite, even after several sexual cycles, restoring their normal frustule size. The parasitoids from $C$. wailesii and $C$. granii were maintained using $C$. concinnus cell lines for the long-term dual culture, after the original host became resistant. As the virulence of these strains were very similar, only one strain originating from C. concinnus (OoCc18) and one from P. intermedia (OoPl) were maintained. Attempts were also made to establish a stable host and parasite culture of the epiphytic diatoms (L. abbreviata, S. ulna, S. unipunctata, A. longipes), using a variety of enrichment media, e.g. modified Wright-Chu (WC) medium dissolved in autoclaved seawater, and diatom artificial medium (DAM), but only A. longipes and T. nitzschioides were successfully cultivated, but without the parasite.

\section{Cross-infection trials}

Cross-infection trials performed in the present study showed that under laboratory conditions the parasitoids from $C$. concinnus and $P$. intermedium were able to infect the other host. 


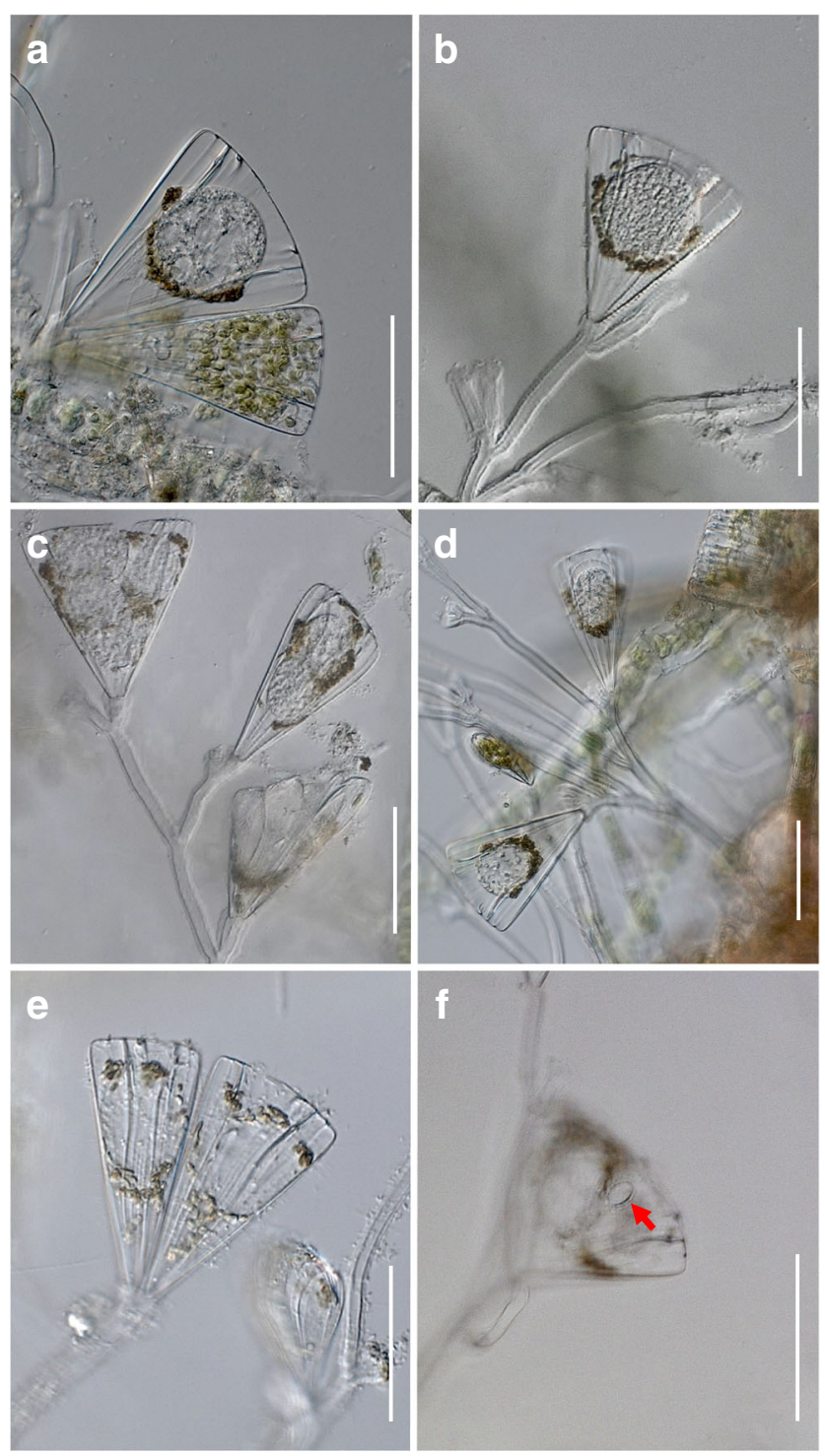

Fig. 1 DIC-light micrographs of Diatomophthora perforans at different life cycle stages in Licmophora abbreviata. a Mature thallus with developing vacuoles lined with chestnut brown residues; b differentiation of the parasitoid thallus; $\mathbf{c}$ host with multiple infections; d zoospore differentiation at an early stage; $\mathbf{e}, \mathbf{f}$ empty sporangium, with discharge tube in $\mathbf{f}$ scale bars $=50 \mu \mathrm{m}$ in all pictures

However, it was observed that the behaviour of each parasitoid was different when inoculated to the alternate host. The spread and rate of infection of the parasitoid from $P$. intermedium were noted to be fast in all of the three strains of $C$. concinnus (CC1, $\mathrm{CC} 2, \mathrm{CC} 3)$. In just 3-4 days, many of the $C$. concinnus cells of all three strains had already started to manifest symptoms and after 7-9 days; the majority of the diatoms were visually infected by the parasitoid. After more than 10 days, the majority of parasitoid thalli had already undergone zoospores discharge, resulting in a high zoospore concentration. However, a few ( $\sim 10$ cells) C. concinnus cells remained uninfected and stopped to reproduce but underwent sexual reproduction (auxosporulation). When the progenies of these uninfected $C$. concinnus cells were inoculated with fresh parasitoids from $P$. intermedium, a very low infection rate was noted, and about half of the cells remained uninfected.

The infection behaviour of the parasitoid from C. concinnus inoculated on three strains of $P$. intermedium (PL1, PL2, PL3) was different as compared to the previous one. Symptoms of infection were noted only after 4-6 days, and the thallus development was observed to be much slower in P. intermedium as compared to $C$. concinnus. However, after 8-10 days, the visual infection rate increased to almost half of the host cells. After that, the infection rate gradually increased, and many zoospores were observed swimming freely in the medium, similar to the abovementioned parasitoid strain. About 2 weeks after this, the majority of the healthy cells were completely devoured. Only few uninfected $P$. intermedium remained, which continued to divide and were infected successively. But after several generations (3-5 months), the algal host underwent sexual reproduction, and most of its progeny became resistant to the parasitoid upon inoculation with fresh parasitoid cells from C. concinnus.

Morphology and life cycle observations The morphology of the parasitoids isolated in the present study agreed well with E. perforans described by Petersen (1905), except for that he described the species as uniflagellate (but see notes in the Taxonomy section). The life cycle of the isolates, from the start of infection until zoospores release was followed using several specimens of each host diatom, L. abbreviata (Fig. 1af), S. ulna (Fig. 2a-d), C. concinnus (Fig. 3a-e; Fig. 5b, c) and P. intermedium (Fig. 4a-g; Fig. 5a, d).

\section{Diatomophthora perforans ex Licmophora abbreviata (Fig. 1)}

Host cells normally contained one spherical, lenticular to irregularly saccate endobiotic holocarpic thallus, and rarely more than 10 infections. The amorphous, opaque, silvery thalli with a thin, colourless wall were $26-40 \mu \mathrm{m}$ by $20-35 \mu \mathrm{m}$ in size as viewed from above, occasionally pushing apart the host valves at maturity, causing slight hypertrophy. The infection started when an encysted spore on the outer surface of the host frustule underwent germination, growing a very thin penetration tube, piercing the diatom wall through the girdle bands, elongating into the host protoplasm close to the algal nucleus. Once interaction was established, rapid thallus development and growth started, gradually deforming the host chloroplasts. Once highly refractive granules appeared, the thallus stopped growth and was surrounded by few chestnut brown residues derived from the host chloroplasts and cytoplasm on both, or sometimes only on one pole. Subsequently, the granular protoplasm became finer for some time, and then irregularly shaped zoospore initials began to appear, which slowly underwent maturation. At the same time, one to more than five broadly conical discharge tubes of usually $8-10 \mu \mathrm{m}$ in length 
Fig. 2 DIC light micrographs of Diatomophthora perforans subsp. norvegica at different life cycle stages in Synedra ulna. a, b Clusters of infected diatoms each containing mature parasitoid thallus; $\mathbf{c}$ two empty sporangium with column of discharge tubes (red arrow); $\mathbf{d}$ colony of $S$. ulna attached to their red algal substrata with multiple infected diatoms. Scale bars $=50 \mu \mathrm{m}$ in all pictures
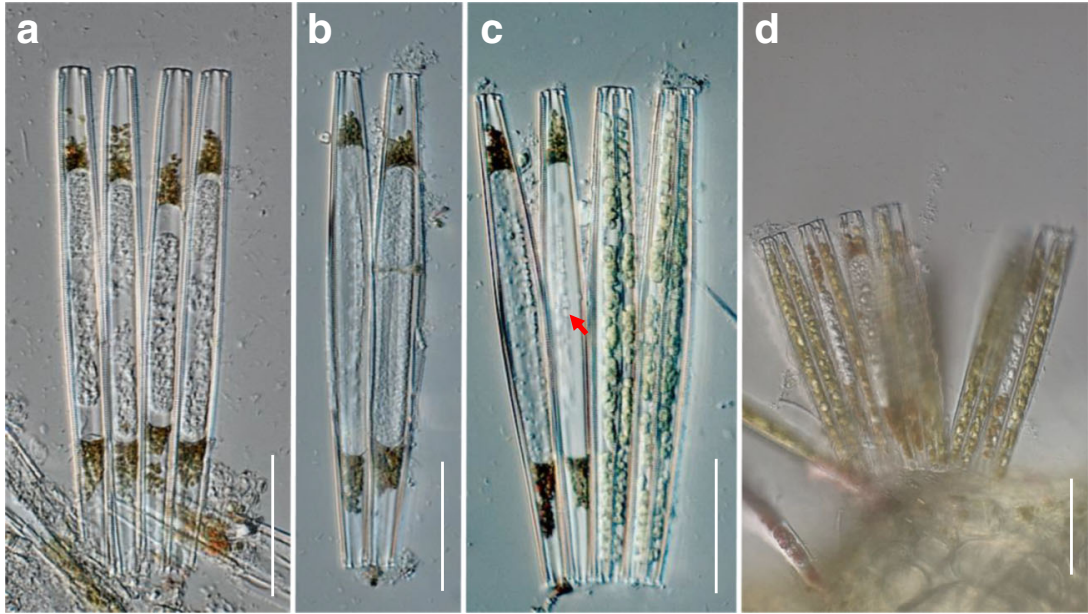

and 9-12 $\mu \mathrm{m}$ in diameter developed, which were somewhat thickened at the base. Zoospores become briefly motile within the sporangium shortly before discharge by individual emergence through the conical exit tube, often within seconds, upon which they were swimming away randomly with an irregular rotation. The pyriform zoospores were about $3 \mu \mathrm{m}$ long and $2 \mu \mathrm{m}$ broad, slightly curved, with two subapically inserted oppositely directed flagella, and an anterior refractive droplet. After a few minutes of motility, zoospores came to a rest, developing into spherically shaped cysts of $2.5-3 \mu \mathrm{m}$ in diameter with a smooth and thick, colourless wall with dimly visible globular contents. Germination of the resting spores was not observed, and the zoospores exhibited no clear diplanetism in our observations. The entire parasitoid thallus and especially the discharge orifice were tested positive for the presence of cellulose, as evidenced by a strong blueish to violet colour after staining with a solution of zinc iodine and chloride.

\section{Diatomophthora perforans ex Synedra ulna (Fig. 2)}

Host cells normally contained one or two broadly tubularshaped endobiotic holocarpic thalli; rarely, more than four simultaneous infections were observed. The amorphous, opaque, silvery thalli were 130-170 $\mu \mathrm{m}$ long and 12-20 $\mu \mathrm{m}$ broad, did neither cause hypertrophy nor distortion of the host valves at maturity, and had a thin colourless wall. Zoospore
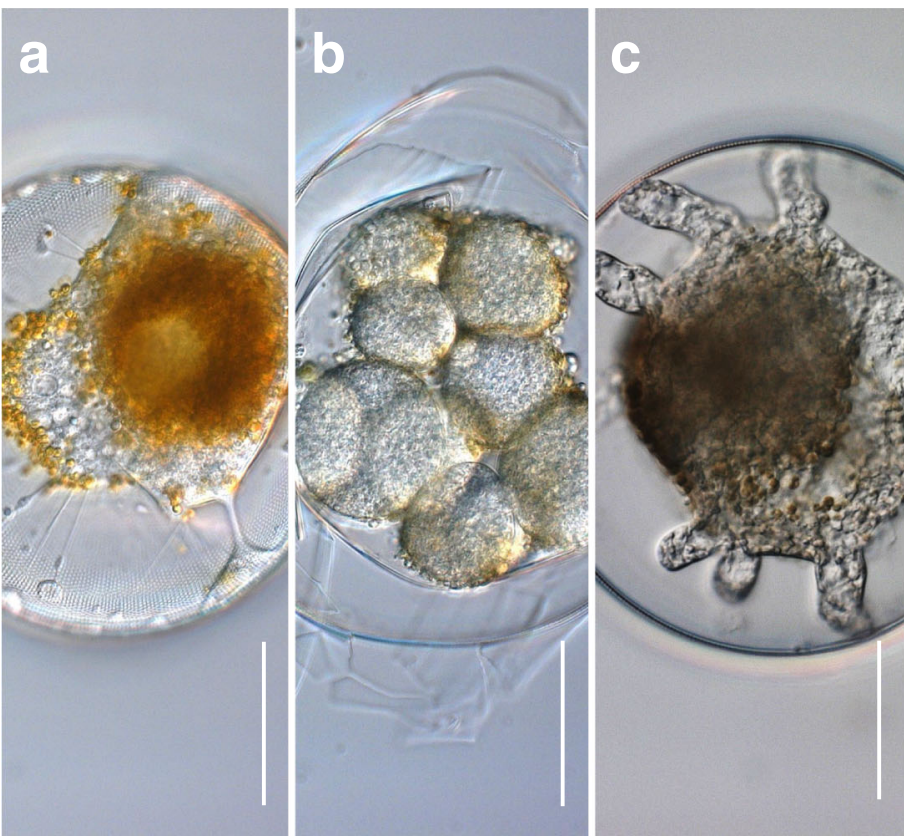
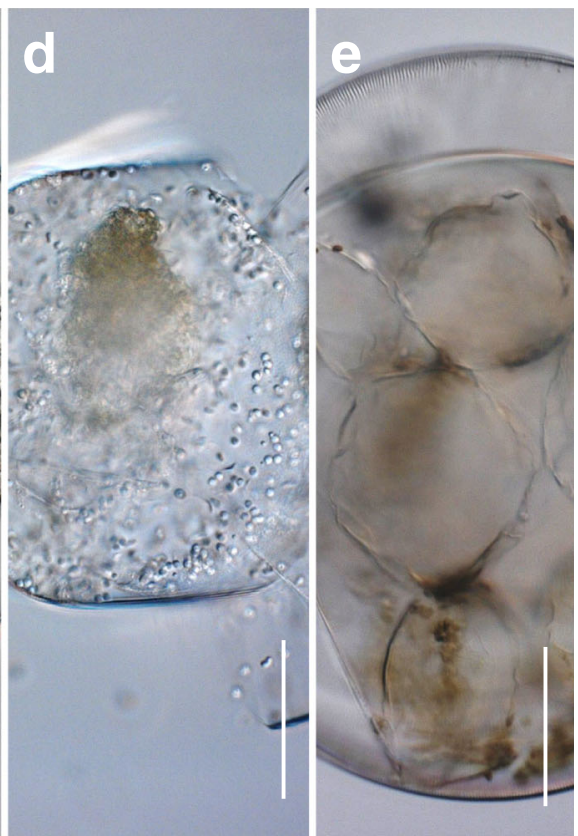

Fig. 3 DIC light micrographs of Diatomophthora perforans subsp. destruens at different life cycle stages in Coscinodiscus concinnus. a Infection at an early stage; b host with mature thalli from multiple infections of the parasitoid; c thallus differentiation with fully formed, multiple discharge tubes; $\mathbf{d}$ zoospores release; e empty sporangium. Scale bars $=50 \mu \mathrm{m}$ in all pictures 


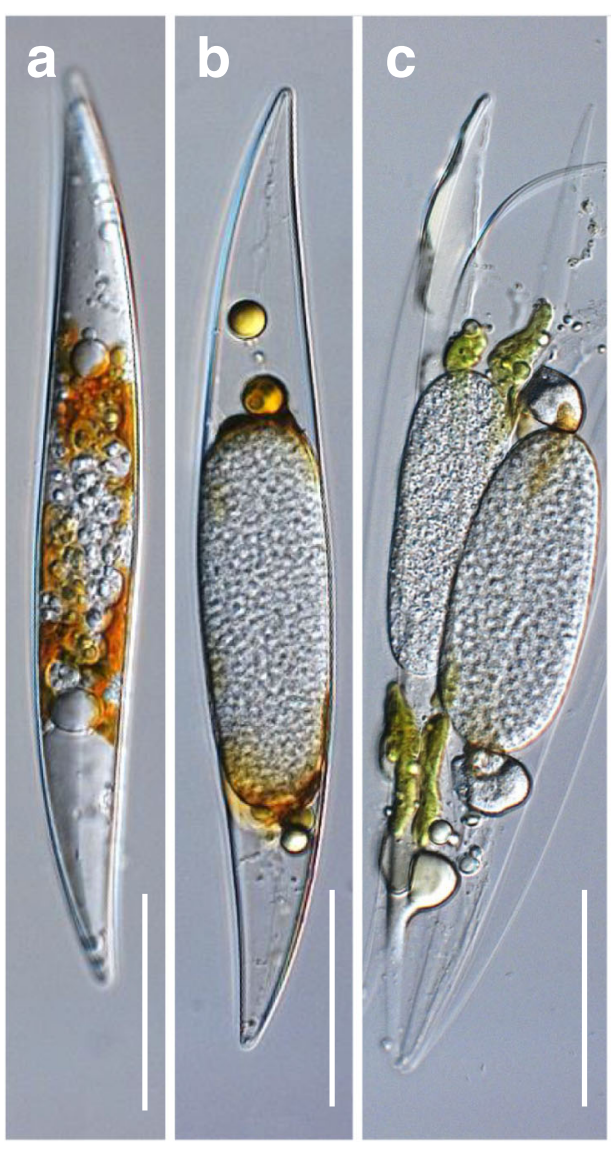

Fig. 4 DIC light micrographs of Diatomophthora perforans subsp. pleurosigmae at different life cycle stages in Pleurosigma intermedium. $\mathbf{a}$ Infection at an early stage; $\mathbf{b}$ thallus maturation; $\mathbf{c}, \mathbf{d}$ multiple infections

cyst formation, penetration and the start of the infection process were similar to $D$. perforans in L. abbreviata. Cysts germinated with a very thin penetration tube, piercing the diatom wall through the girdle bands, and forming a small thallus that is crossing the host cytoplasm until close to the nucleus of the diatom. Once established, it underwent rapid thallus enlargement, which usually started close to the nucleus, gradually deforming the host chloroplasts, elongating into highly refractive granules; the maturing sporangium was restricted by the cell walls, therefore assuming a cigar-shaped appearance. At this stage, the host cytoplasm and the chloroplasts had completely disintegrated resulting in orange-brown to chestnut-coloured granules at the opposite apices of the frustules. After some time, the granular protoplasm became coarser, forming irregularly shaped 'droplets' of zoospores initials. At this stage, 8 to more than 20 discharge tubes of 3-5 $\mu \mathrm{m}$ in diameter per parasitoid thallus formed where it was appressed to the girdle bands. The exit tubes had a distinctly thickened base, which is circular when single to confluent when forming in rows. After maturation, zoospores became briefly motile within the sporangium, shortly before discharge, and underwent release in seconds, emerging individually through the multiple exit tubes, swimming away randomly in uneven

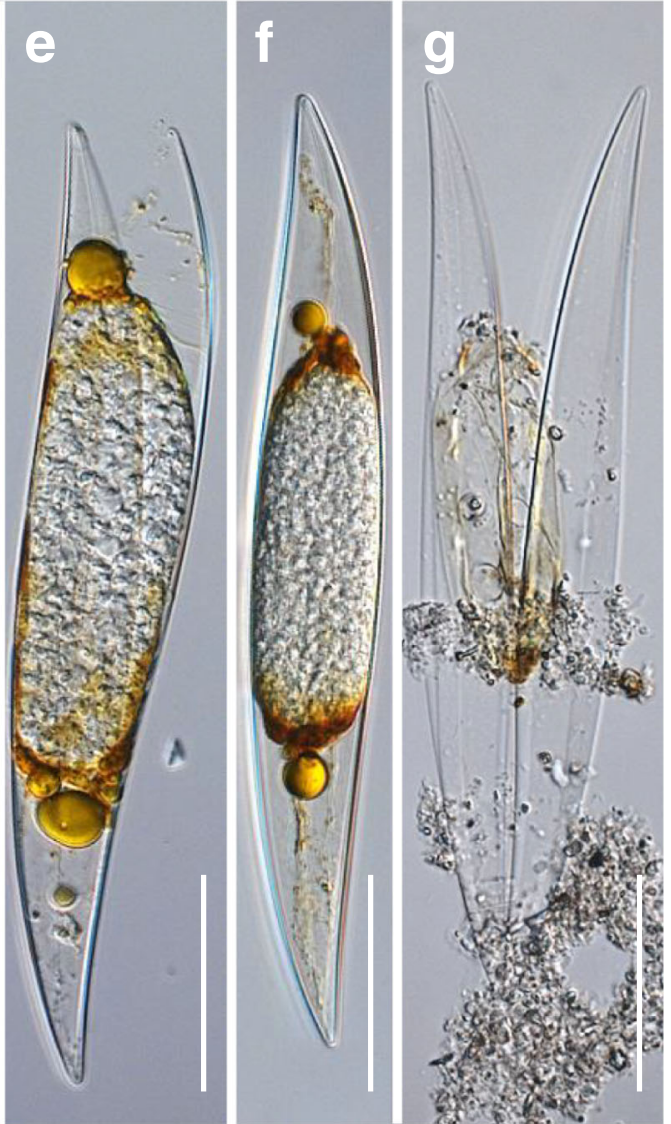

on a single host resulting in two (c) and three (d) thalli of the parasitoid; e, f thallus differentiation with visible zoospores initials; $g$ empty sporangium. Scale bars $=50 \mu \mathrm{m}$ in all pictures

rotation. The pyriform zoospores were about $3 \mu \mathrm{m}$ long by $2 \mu \mathrm{m}$ broad, with an anterior refractive droplet, slightly curved with two subapically inserted flagella that were oppositely directed. After a few minutes of motility, zoospores came to a rest, forming spherical shaped cysts of $1.5-3 \mu \mathrm{m}$ in diameter with a smooth and thick, colourless wall, and with dimly visible globular contents. The germination of the resting spores was not observed. The zoospores exhibited no observed diplanetism. The entire parasitoid thallus was tested positive for the presence of cellulose, especially the thickened portion of the exit tubes attained a very strong bluish to violet colouration after staining with zinc iodine and chloride solution (Fig. 5e).

\section{Diatomophthora perforans ex Coscinodiscus concinnus (Fig. 3)}

Host cells normally contained one to eight spherical to subspherical, endobiotic and holocarpic thalli, but occasionally more than 20. In fresh field samples, multiple infections were uncommon, but in laboratory cultures, multiple infections per host diatom were frequent, likely because of the high concentration of zoospores present, and often almost all parts 


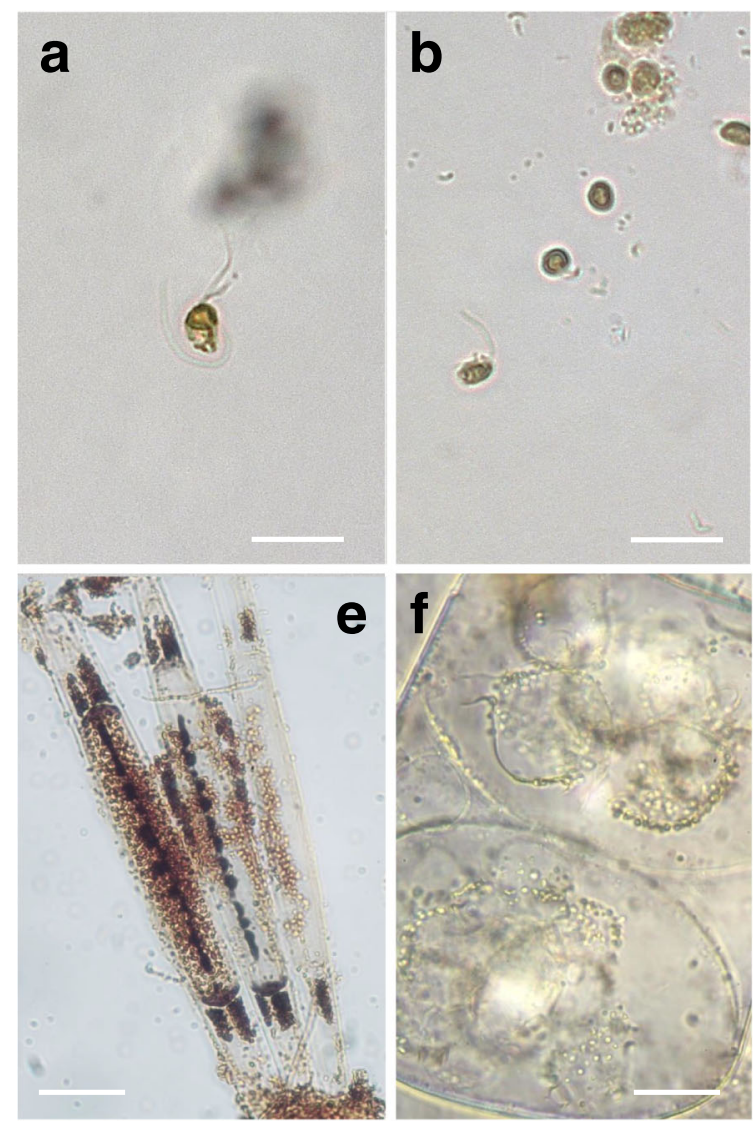

Fig. 5 DIC light micrographs of different sporulation stages. a Newly released biflagellate zoospore of $D$. perforans subsp. pleurosigmae. $\mathbf{b}$ Cysts of D. perforans subsp. destruens; c zoospores trapped within a C. concinnus frustule; $\mathbf{d}$ encysted zoospores attached to the outer frustule of $C$. concinnus. e Exit tubes of D. perforans subsp. norvegica.

of the diatom girdle were decorated by quiescent zoospores (Fig. 5c). The amorphous, opaque, silvery thalli were 70 $160 \mu \mathrm{m}$ in diameter, with colourless thin wall. They neither pushed apart host valves nor caused hypertrophy at maturity. Zoospore encystation and penetration, as well as the start of the infection process were similar to E. perforans from L. abbreviata and from S. ulna. Cysts germinated to produce a very thin penetration tube, piercing the diatom wall at the girdle bands through the cingula, and extending into the host protoplasm until close to the host nucleus. Once established, the thalli underwent fast enlargement, gradually distorting the host chloroplasts and cytoplasm, eventually dissolving everything inside, mostly forming no pronounced residues. At full maturity, the dense hyaline protoplast of the thalli got coarser and granular 'droplets' began to appear, which underwent differentiation into irregularly shaped zoopore initials. Before zoospores were produced, three to seven discharge tubes of unequal length (usually $40-70 \mu \mathrm{m}$ long by 9 $15 \mu \mathrm{m}$ in diameter) with a very slightly thickened base simultaneously developed on each sporangium without an obvious pattern, but did not extend beyond the host frustule. After
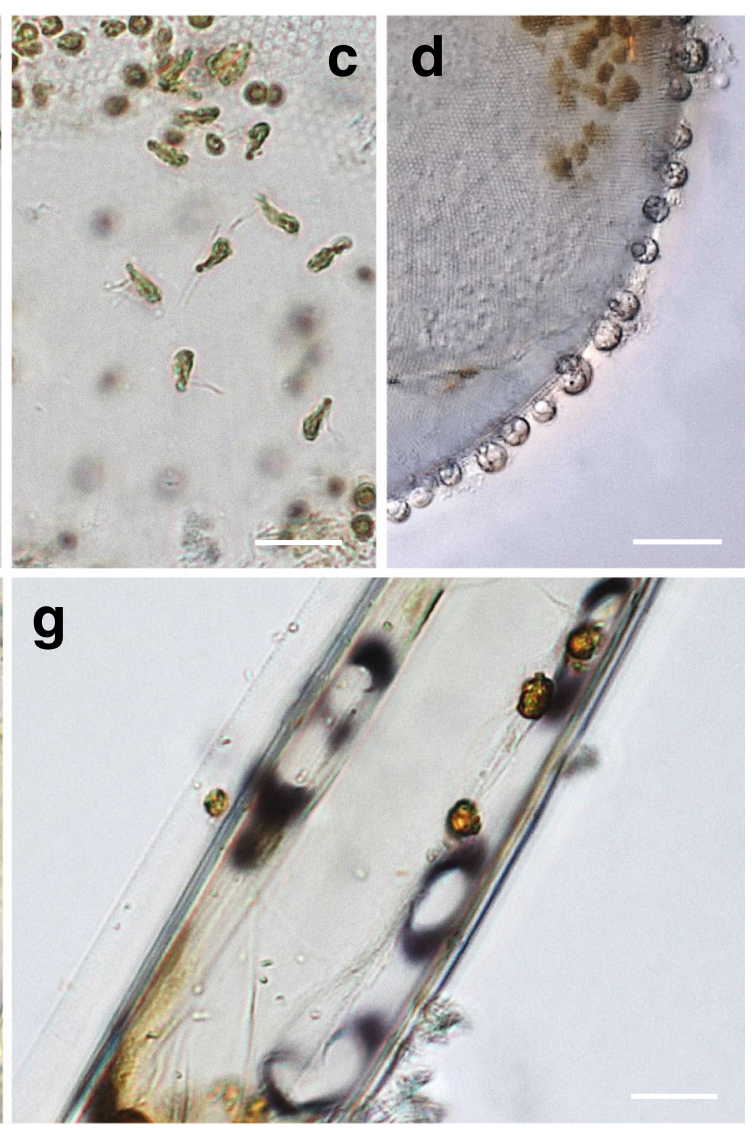

f Exit tubes of $D$. perforans subsp. destruens. $\mathbf{g}$ Exit tubes of $D$. perforans subsp. pleurosigmae. The base of the tubes reveal a dark blue to violet colouration after staining with chloride-zinc and iodine when the thallus is attached to the girdle bands. Scale bars $20 \mu \mathrm{m}$ in all pictures, except for (e) and (f) (about $30 \mu \mathrm{m}$ )

maturation, zoospores became motile within the sporangium shortly before discharge through the multiple exit tubes. The zoospores swam away randomly in uneven rotation, but were also often trapped inside the host frustule, squeezing through the girdle zone for emergence, when the exit tubes did not reach the surrounding medium. The pyriform zoospores were 3-6 $\mu \mathrm{m}$ long by $2.5-4 \mu \mathrm{m}$ broad, slightly curved with two oppositely directed, apically inserted flagella and an with anterior refractive droplet. After a few minutes of motility, zoospores came to a rest, giving rise to spherical cysts of $2.5-3 \mu \mathrm{m}$ in diameter (Fig. 5b), with a smooth, thick, colourless wall, and with dimly visible globular contents. A zoospore diplanetism was not observed. Germination of the resting spores was not observed, but after several days, motile pyriform zoospores were found to be escaping from destroyed portions of the host frustules (usually through opened girdle bands), and these spores were assumed to have emerged from resting spores, which were often observed within destroyed hosts. The entire parasitoid thallus was tested positive for the presence of cellulose, as evidenced by a bluish to violet colour after 
staining with chloride-zinc and iodine solution, but was very thin-walled. As the base of the discharge tube was only very slightly thickened, there was no strong staining of this portion of the thallus, as well (Fig. 5f).

\section{Diatomophthora perforans ex Pleurosigma intermedium (Fig. 4)}

Single host cells normally contained one broadly tubular endobiotic holocarpic thallus, but occasionally more than 5 , even up to 30 , compacted tightly within the frustule. The amorphous, opaque, silvery thallus was 90-120 $\mu \mathrm{m}$ long by $30-60 \mu \mathrm{m}$ in diameter when singly, but as small as 40 $20 \mu \mathrm{m}$ long by $8-15 \mu \mathrm{m}$ in diameter when multiple infections were present. Infections caused slight hypertrophy, and the thallus growth forced apart the host valves at thallus maturity. The thalli had a thin colourless wall. The infection cycle started when zoospores encysted on the host and a penetration tube was formed, similar to the situation of $D$. perforans on L. abbreviata and the other hosts described in this study. Cysts germinated producing a very thin penetration tube, piercing the diatom wall through the girdle bands, and extending into the host protoplasm until close to the diatom nucleus. Once established, the thallus underwent rapid growth, which usually started close to the nucleus, gradually deforming the host chloroplasts. The maturing sporangium disintegrated the host chloroplasts, reducing them and the cytoplasm to orange-brown to chestnut-coloured residues at the apices of the host frustules. After some time, the protoplasm of the parasitoid thallus became coarser and granular, forming irregularly shaped zoospores initials that underwent further differentiation and maturation. At this stage, 4 to more than 8 very short tubular discharge tubes formed per parasitoid thallus without a strong pattern, with $7-12 \mu \mathrm{m}$ in diameter, and with a thickened base. After zoospore maturation, they became motile within the sporangium shortly before discharge and underwent release within seconds, emerging individually through the multiple exit tubes, swimming away randomly in uneven rotation. The pyriform zoospores were 3-6 $\mu \mathrm{m}$ long by $2.5-4 \mu \mathrm{m}$ broad, slightly curved with two oppositely directed, apically inserted flagella and an anterior refractive droplet (Fig. 5a). After a few minutes of motility, zoospores started to rest. Subsequently, they developed into spherical spores of 2.5-3 $\mu \mathrm{m}$ in diameter with a smooth, with thick, colourless wall, and with dimly visible globular contents. Germination of the resting spores was not observed, and zoospore diplanetism was not observed. The entire parasitoid thallus tested positive for the presence of cellulose; especially the thickened portion of the exit tubes that exhibited a strong blueish to violet colouration after staining with zinc iodine and chloride solution (Fig. 5g).
Molecular phylogeny In the phylogenetic reconstructions based on nrSSU sequences (Fig. 6), Diatomophthora perforans isolated from Licmophora cf. abbreviata (sample A, sample B), S. ulna, C. concinnus (sample A, sample B) and P. intermedium grouped together with strong to maximum support in all analyses. Interestingly, the sequences were grouped according to their host genus with strong to maximum support. Collectively, they clustered together with the freshwater diatom parasitoid Diatomophthora gillii, the marine diatom pathogen $D$. drebesii and three other environmental sequences within the newly erected genus Diatomophthora (Buaya and Thines 2020 ) with varying support. This monophyletic clade of diatom parasitoids showed some affinities with Pontismatales and Anisolpidiales. Apart from L. coscinodisci and Ectrogella bacillariacearum, all other holocarpic parasitoids of diatoms branched before the split of Saprolegniomycetes and Peronosporomycetes. Miracula helgolandica, a parasite of the marine pennate diatom Pseudo-nitzschia pungens, and Miracula moenusica, a parasite of the brackish diatom Pleurosira laevis, together with two other undescribed environmental sequences, formed the earliest-diverging lineage of the oomycetes. The exact branching of the early-diverging lineages of the Oomycota was poorly resolved, but the Oomycota as a whole were resolved as monophyletic and as a sister clade to the marine zoosporic protist Developayella.

\section{Taxonomy}

Based on the life cycle traits, host range, and phylogenetic placement, a new combination is introduced here, as well as three subspecies within Diatomophthora perforans.

Diatomophthora perforans (H.E. Petersen) A.T. Buaya \& Thines, comb. nov, MycoBank MB 834524, (Fig. 1)

Basionym: Ectrogella perforans H.E. Petersen. Oversigt over det Kongelige Danske Videnskabernes Selskabs Forhandlinger og dets Medlemmers Arbeider 5:466 (1905)

Type: Danmark, Oversigt over det Kongelige DanskeVidenskabernes Selskabs Forhandlinger og dets Medlemmers Arbeider 5 (1905), p.467, Fig. VII/1, lectotypus designated here, MBT390815. Note that the host seems to have single diatoms on the branches and rather stout frustules, a feature that is typical for L. abbreviata s.l., on which the species was also observed in the present study. Norway, Oslo Fjord, 19 September 2017, isolated by Anthony Buaya, FR-0046124, epitytus designated here, MBT390816. Ex-type partial nrSSU sequence MN764292.

Notes: In his original description, Petersen (1905) mentioned just one anterior flagellum for which seems to be contradictory to the ex-epitype isolate that has two oppositely directed flagella. However, as the flagella are inserted subapically, the posteriorly directed and not very active whiplash flagellum is difficult to spot even with modern light 


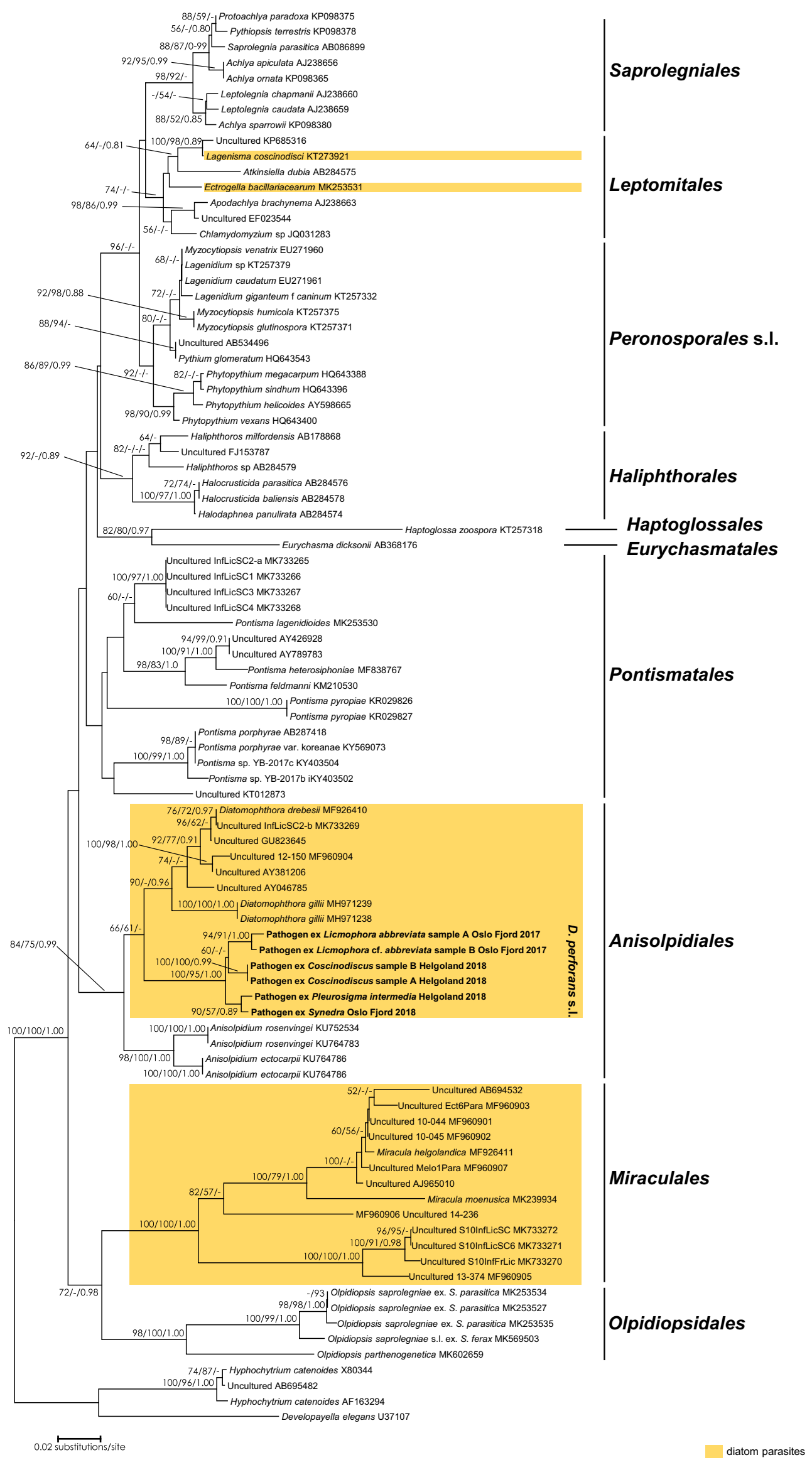


Fig. 6 Molecular phylogeny based on minimum evolution analysis inferred of partial nrSSU sequences. Numbers on branches denote bootstrap values from minimum evolution, maximum likelihood, and Bayesian analyses, in the respective order. A dash "-" indicates less than $50 \%$ bootstrap support for the presented or a conflicting topology

microscopes, because it is often tightly attached to the zoospore body. Thus, it is conceivable that it was simply overlooked by Petersen (1905).

Diatomophthora perforans subsp. norvegica A.T. Buaya \& Thines, subsp. nov., MycoBank MB 834525 (Fig. 2)

Etymology: Referring to the country where this parasitoid subspecies was isolated.

Type: Norway, Oslo Fjord, 23 September 2017, isolated by Anthony Buaya, FR-0046120 (holotype). Ex-type partial nrSSU MN764298.

Diagnosis: Differs from Diatomopththora perforans subsp. perforans and the other two subspecies by its elongated spherical "cigar-shaped" mature thallus, its multiple, tiny, conical discharge tubes, and its host in Bacillariophyceae.

Description: Thallus holocarpic, normally one, rarely two to four endobiotic in S. ulna, naked at early development, surrounded by thin, colourless, smooth wall, tubular-shaped at maturity (130-170 $\mu \mathrm{m}$ long by $12-20 \mu \mathrm{m}$ in diameter), almost filling the host frustule, disintegrating the host chloroplasts, forming pronounced residual plugs at opposite thallus apices, not causing hypertrophy; with 8-20 flattened discharge tubes of 6-3 $\mu \mathrm{m}$ in diameter, with thickened based, forming along the mid girdle valves; zoospores pyriform (3 $\mu \mathrm{m}$ long by $2 \mu \mathrm{m}$ wide), biflagellate, with anterior refractive droplet, swarming inside sporangium prior to release; resting spore spherical (1.5-3 $\mu \mathrm{m}$ in diameter), smooth walled.

Known distribution: Oslo Fjord, Norway

Diatomophthora perforans subsp. destruens A.T. Buaya \& Thines, subsp. nov., MycoBank MB 834527 (Fig. 3).

Etymology: "destruens" derived from Latin, refers to the high virulence against the diatom genus Coscinodiscus (especially C. concinnus).

Type: Germany, Helgoland, Helgoland Roads, North Sea, 6 December 2017, isolated by Anthony Buaya, FR-0046118 (holotype). Ex-type partial nrSSU MN764256.

Diagnosis: Differs from Diatomopththora perforans subsp. perforans and the two other subspecies by its long tubular discharge tubes, the way of zoospores release, and its hosts in Coscinodiscophyceae.

Description: Thallus holocarpic, normally one to eight, rarely more than 20 endobiotic in Coscinodiscus (C. concinnus, C. granii, C. wailesii), naked at early development, surrounded by a thin, colourless smooth wall, spherical subspherically shaped at maturity (70-160 $\mu \mathrm{m}$ in diameter), disintegrating the host chloroplast, do not form residual plugs, do not cause hypertrophy; usually with 3-7 tubular discharge tubes of $40-70 \mu \mathrm{m}$ in length by $9-15 \mu \mathrm{m}$ in diameter, with a very slightly thickened based, do not protrude outside; zoospores pyriform (3-6 $\mu \mathrm{m}$ long by $2.5-4 \mu \mathrm{m}$ wide), biflagellate, with anterior refractive droplet, begining their movement inside sporangium; resting spore spherical $(2.5-3 \mu \mathrm{m}$ in diameter), smooth walled.

Known distribution: Helgoland Roads, North Sea, Germany

Diatomophthora perforans subsp. pleurosigmae A.T. Buaya \& Thines, subsp. nov., MycoBank MB 834528 (Fig. 4)

Etymology: Named after its host $P$. intermedium

Type: Germany, Helgoland, Helgoland Roads, North Sea, 6 December 2017, isolated by Anthony Buaya, FR-0046117 (holotype). Ex-type partial nrSSU MN764291.

Diagnosis: Differs from Diatomopththora perforans and the two other subspecies by its broadly tubular mature thallus, its flattened multiple discharge tubes and its host in Licmophorales.

Description: Thalli holocarpic, normally one to five, rarely more than 30 endobiotic in Pleurosigma intermedium, naked at early development, surrounded by a thin colourless smooth wall, broadly tubular at maturity (90-120 $\mu \mathrm{m}$ long by 30 $60 \mu \mathrm{m}$ in diameter), disintegrating the host chloroplast, forming thin residual plugs at thallus opposite apices with lipid globules, causing hypertrophy; normally, with 4 to 8 very short tubular discharge tubes of 7-12 $\mu \mathrm{m}$ in diameter, with very thickened based, slightly protruding outside; zoospores pyriform (3-6 $\mu \mathrm{m}$ long by $2.5-4 \mu \mathrm{m}$ broad), biflagellate, with anterior refractive droplet, swarming inside the sporangium before release; resting spore spherical (2.5-3 $\mu \mathrm{m}$ in diameter), smooth walled.

Known distribution: Helgoland Roads, North Sea, Germany

\section{Discussion}

The majority of the biotrophic parasitoids of diatoms were assigned to the genus Ectrogella, and some to the genus Olpidiopsis and Lagenidium (Sparrow 1960; Buaya et al. 2017). Only recently, the phylogenetic affinity and taxonomy of the type species of Olpidiopsis, O. saprolegniae (Buaya et al. 2019b) and E. bacillariacearum (Buaya and Thines 2020) were resolved, enabling a revision of those diatom parasitoids formally described that neither belonged to the crown oomycetes nor to Miracula. Consequently, two diatom parasitoids were re-classified to the genus Diatomophthora (Buaya and Thines 2020), to which we add Diatomophthora perforans in the current study.

Of the marine species previously assigned to Ectrogella, $D$. perforans is the most well-known species and is reported 
sporadically, especially in species of the genus Licmophora (Petersen 1905; Sparrow 1936, 1960; Johnson 1967), even though other hosts have also been reported (for a summary see Sparrow 1960). It has been speculated that $D$. perforans might be conspecific with $E$. licmophorae because of some similarities, e.g. similar thallus shape and host range (Sparrow 1960; Dick 2001). However, D. perforans exhibits an olpidiopsis-like zoospore release (zoospores begin swarming in the sporangium and swim away after discharge) rather than an achlya-like release (aplanospores that are encysting on the discharge tube orifice until secondary zoospores hatch) typical for the latter (Sparrow 1960; Johnson 1967; Raghukumar 1980a). Zoospore release in $C$. concinnus differs from that in other hosts, as the parasitoid does not force apart the host frustule and undergoes zoospore release internally, similar to E. gomphonematis and E. eurychasmoides (Scherffel 1925; Feldmann and Feldmann 1955). The presence of a basal thickening of the exit tube, as well as its thickness is probably dependent on the force needed to press the discharge tube through the space between the frustules. This Spreizkörper or Spreizapparat (Zopf 1884; Friedmann 1952; Johnson 1966) develops at an early stage of discharge tube development (Scherffel 1925), and, if no immediate force is needed in its development (e.g. in D. perforans subsp, destruens in Coscinodiscus), additional wall thickening will not take place, as evidenced by the very slight thickening of $D$. perforans isolates on C. concinnus, while the same isolates would form it on P. intermedium. Therefore, this feature seems not to be constant, which is why a differentiation based on it (Garvetto et al. (2018) is probably not reliable.

Sparrow (1936) reported that $D$. perforans zoospores are anteriorly biflagellate and oppositely directed, which is similar to what has been documented in all of the isolates of the current study, and different from previous observations (Petersen 1905, 1909; Höhnk 1939; Aleem 1953). One possible explanation for this is that specimens isolated by above investigators were contaminated with other parasitoids attacking the same host, which was also noted in the study of Garvetto et al. (2020). However, it is probably even more likely, that due to the subapical insertion of the flagella, the posteriorly directed whiplash flagellum, which is sometimes not very active and attached to the zoospore body might have been overlooked. In any case, the characteristic formation of a large amount of discharge tubes, especially on Synedra, was also observed in this study and the behaviour of the zoospores also matches the description of Petersen (1905).

With $D$. perforans, the third species placed into Ectrogella by Dick (2001) has sequence data available. It will be interesting to see, if the other unsequenced diatom-affecting Ectrogella species (E. monostoma, E. gomphonematis, E. licmophorae, E. eunotiae) can be assigned to the two genera, Diatomophthora and Ectrogella. Garvetto et al. (2018, $2020)$ recently observed and characterised several diatom parasites. As shown in this study, their clade designated as
OOM_1 corresponds to the genus Miracula (Buaya et al. 2017), with their sequences designated as OOM_1-1 being not genetically differentiated with $M$. helgolandica, and are probably conspecific with that species. Miracula helgolandica seems to be a very widespread species, especially in higher latitudes (Hassett et al. 2019). The clade designated by Garvetto et al. $(2018,2020)$ as OOM 2 corresponds to the genus Diatomophthora, with one sequence derived from a specimen with Licmophora (Garvetto et al. 2020) probably corresponding to an individual belonging to $D$. drebesii.

It is noteworthy that the tree topology presented in Garvetto et al. $(2018,2020)$ differs markedly from that of Buaya et al. (2017), Buaya and Thines (2020), and this study. The reason for this is most likely that in the former two studies not very stringent alignment parameters were chosen, which, in conjunction with the very divergent sequences, is prone to result in alignment artefacts that in turn lead to a phylogenetic tree not accurately depicting phylogenetic relationships. Support for this is also lent by the fact that the grouping of the Saprolegniomycetes as well as the crown oomycetes received no support, the Leptomitales were not resolved as monophyletic, and the overall rather unbalanced shape of the tree in Garvetto et al. (2020). However, clearly more loci will be required to resolve the relationships of the higher level clades of the early-diverging oomycetes. Also, it can only be speculated about the phylogenetic affinities to other diatom-affecting species, e.g. of the genera Aphanomycopsis (A. bacillariacearum) and Lagenidium (L. enecans, $L$ brachystomum) until sequence data will become available for them.

Multigene analyses and detailed physiological studies will benefit from stable (co-)cultures of the early-diverging oomycetes. In addition to the recent establishment of a hostparasite culture of L. coscinodisci Drebes (Buaya et al. 2019c) on different Coscinodiscus species, in this study, a successful cultivation of Diatomophthora perforans s.l. single spore strains from $P$. intermedium and C. concinnus were also accomplished for more than 2 years by the publication of this manuscript. Interestingly, after several ( $\sim 4-6$ months) periodic transfers, some strains of $C$. concinnus developed resistance to the parasitoid after undergoing a series of auxosporulation, while $P$. intermedium remained susceptible after sexual recombination. Similar observations were also made on a L. coscinodisci culture on its $C$. wailesii host after several months of periodic transfers (Buaya et al. 2019c). Resistance of diatoms to oomycetes and its inheritance have not been studied in detail so far. However, it seems likely that similar to the situation on multicellular organisms, receptors exist that can perceive pathogen attack and take efficient countermeasures to fight off the parasitoid; at the same time, it can be assumed that this is counterbalanced by the rapid adaption of parasitoids to their host genotypes (Thornton 2002; Raven and Waite 2004) and probably by expanding host ranges (Thines 2019). Several factors, e.g. chemical defense, 
genotype adaptation, morphological barriers (frustule thickness, pore size), are known to interfere in host-parasite interaction (Raven and Waite 2004; Pohnert 2005; Pancic et al. 2019; Vallet et al. 2019; Zhang et al. 2017). In crossinfection trials, the spread and rate of infection were noted to be different when two strains of $D$. perforans s.l. where provided with hosts of the other strain. This indicates suboptimal interaction, as sometimes seen in conjunction with host jumps (Thines 2019). The cross-infection trials conducted in this study demonstrated that $D$. perforans can be plurivorous under laboratory conditions. However, there is also a clear phylogenetic structure within the strains sampled, with a grouping according to the host. Thus, it is currently unclear, whether the infection potential noted is due to laboratory conditions, which provide an abundance of stressed hosts, if the species is currently in the differentiation phase after a radiation (Thines 2019), or if the species is plurivorous in natural settings as well and possesses a complex population structure with infrequent sexual reproduction between lineages, similar to the situation in the angiosperm parasite Albugo candida (Jouet et al. 2019; Thines and Kamoun 2010; Thines 2019). We feel that the most likely explanation for the observed structure and the plurivorous nature is that the lineages are currently radiating and speciating, which is the reason why we have described them on the subspecies level. The establishment of a second parasitoid culture with hosts susceptible also to L. coscinodisci opens up the possibility for future studies into the commonality and differences in the interaction of hosts and parasitoids from two phylogenetically largely divergent oomycete clades.

Acknowledgements The Katholischer Akademischer Ausländer-Dienst (KAAD) is gratefully acknowledged for the doctoral scholarship to ATB. The authors are also thankful to Uwe Nettelmann and Eva-Maria Brodte of the AWI-BAH Helgoland for the laboratory support. We would also like to thank the ForBio-Research School in Biosystematics, Natural History Museum-University of Oslo, for the micro-algae taxonomy training and fieldwork assistance to ATB in Norway.

Author contributions ATB and MT conceived the study; AK and ATB provided materials; ATB carried out the experiments; ATB and MT analysed the data; ATB and MT wrote the manuscript, with contributions from the other authors.

Funding information Open Access funding provided by Projekt DEAL. This study has been supported by LOEWE in the framework of the LOEWE Centre for Translational Biodiversity Genomics (TBG), funded by the Ministry of Science of the Government of Hessen.

Open Access This article is licensed under a Creative Commons Attribution 4.0 International License, which permits use, sharing, adaptation, distribution and reproduction in any medium or format, as long as you give appropriate credit to the original author(s) and the source, provide a link to the Creative Commons licence, and indicate if changes were made. The images or other third party material in this article are included in the article's Creative Commons licence, unless indicated otherwise in a credit line to the material. If material is not included in the article's Creative Commons licence and your intended use is not permitted by statutory regulation or exceeds the permitted use, you will need to obtain permission directly from the copyright holder. To view a copy of this licence, visit http://creativecommons.org/licenses/by/4.0/.

\section{References}

Aleem AA (1953) Marine fungi from the west-coast of Sweden. Ark Bot $3: 1-33$

Badis Y, Klochkova TA, Strittmatter M, Garvetto A, Murúa P, Sanderson CJ, Kim G-H, Gachon CMM (2019) Novel species of the oomycete Olpidiopsis potentially threaten European red algal cultivation. J Appl Phycol 31:1239-1250

Beakes GW, Thines M (2017) Hyphochytriomycota and Oomycota. In: Archibald JM, Simpson AGB, Slamovits CH (eds) Handbook of the Protists. Springer Verlag, Heidelberg, pp 435-505

Buaya AT, Thines M (2019) Miracula moenusica, a new member of the holocarpic parasitoid genus from the invasive freshwater diatom Pleurosira laevis. Fuse 3:19-33

Buaya AT, Thines M (2020) Diatomophthoraceae-a new family of olpidiopsis-like diatom parasitoids largely unrelated to Ectrogella. Fuse 5:113-118

Buaya AT, Ploch S, Hanic L, Nam B, Nigrelli L, Kraberg A, Thines M (2017) Phylogeny of Miracula helgolandica gen. et sp. nov. and Olpidiopsis drebesii sp. nov. two basal oomycete parasitoids of marine diatoms, with notes on the taxonomy of Ectrogella-like species. Mycol Prog 16:1041-1050

Buaya AT, Ploch S, Thines M (2019a) Rediscovery and phylogenetic placement of Olpidiopsis gillii (de Wildeman) Friedmann, a holocarpic oomycete parasitoid of freshwater diatoms. Mycoscience 60:141-146

Buaya AT, Ploch S, Inaba S, Thines M (2019b) Red algal Olpidiopsis are not Olpidiopsis. Fuse 4:21-31

Buaya AT, Kraberg A, Thines M (2019c) Dual culture of the oomycete Lagenisma coscinodisci Drebes and Coscinodiscus diatoms as a model for plankton/parasite interactions. Helgol Mar Res 73:2

Dick MW (2001) Straminipilous Fungi. Kluwer, Dordrecht

Drebes G (1968) Lagenisma coscinodisci gen. nov. sp. nov., ein Verterer der Lagenidiales in der marinen Diatomee Coscinodiscus. Veröff Inst Meeresf Bremerhaven 3:67-70

Edgar RC (2004) MUSCLE: multiple sequence alignment with high accuracy and high throughput. NAR 32:1792-1797

Feldmann J, Feldmann G (1955) Observations sur quelques Phycomycetes marins nouveaux ou peu connus. Rev Mycol 20: $231-251$

Friedmann I (1952) Über neue und wenig bekannte auf Diatomeen parasitierende Phycomyceten. Österr Bot Z 99:173-219

Garvetto A, Nézan E, Badis Y, Bilien G, Arce P, Bresnan E, Gachon CMM, Siano R (2018) Novel widespread marine oomycetes parasitising diatoms, including the toxic genus Pseudo-nitzschia: genetic, morphological, and ecological characterisation. Front Microbiol 9:2918

Garvetto A, Perrineau MM, Dressler-Allame M, Bresnan E, Gachon CMM (2020) "Ectrogella" parasitoids of the diatom Licmophora sp. are polyphyletic. J Eukaryot Microbiol 67:18-27

Guillard RR, Ryther JH (1962) Studies of marine planktonic diatoms: I. Cyclotella nana Hustedt, and Detonula confervacea (Cleve) Gran. Can J Microbiol 8:229-239

Hassett BT, Thines M, Buaya A, Ploch S, Gradinger R (2019) A glimpse into the biogeography, seasonality, and ecological functions of arctic marine Oomycota. IMA Fungus 1:6

Höhnk W (1939) Ein Beitrag zur Kenntnis der Phycomyceten des Brackwassers. Kiel Meeresforsch 3:337-361 
Johnson TW (1966) Ectrogella in marine species of Licmophora. J Elisha Mitchell Sci Soc 82:25-29

Johnson TW (1967) Monocentric fungi on species of Rhizosolenia from saline habitats. Mycopathol Mycol Appl 32:281-290

Jouet A, Saunders DGO, McMullan M, Ward B, Furzer O, Jupe F, Cevik V, Hein I, Thilliez GJA, Holub E, van Oosterhout C, Jones JDG (2019) Albugo candida race diversity, ploidy and host-associated microbes revealed using DNA sequence capture on diseased plants in the field. New Phytol 221:1529-1543

Karling JS (1942) The simple holocarpic biflagellate Phycomycetes. Published by Karling JS, New York

Kraberg A, Rodriquez N, Salewski CR (2015) Historical phytoplankton data from Helgoland Roads: can they be linked to modern time series data? J Sea Res 101:51-58

Kristiansen S, Farbrot T, Naustvoll LJ (2001) Spring bloom nutrient dynamics in the Oslofjord. Mar Ecol Prog Ser 219:41-49

Pancic M, Torres RR, Almeda R, Kiørboe T (2019) Silicified cell walls as a defensive trait in diatoms. Proc R Soc B 286:20190184

Petersen HE (1905) Contributions a la connaissance des Phycomycetes marins (Chytridineae Fischer). Oversigt Kong Danske Videnskab Selskabs Forhand 5:439-188

Petersen HE (1909) Note sur les Phycomycetes observes dans les teguments vides des nymphes de Phryganees avec description de trois especes Nouvelles de Chytridinees. Aust J Bot 17:214-222

Pohnert G (2005) Diatom/copepod interactions in plankton: the indirect chemical defense of unicellular algae. Chembiochem 6:946-959

Raghukumar C (1978) Physiology of infection of the marine diatom Licmophora by the fungus Ectrogella perforans. Veröff Inst Meeresf Bremerhaven 17:1-14

Raghukumar C (1980a) An ultrastructural study of the marine diatom Licmophora hyalina and its parasite Ectrogella perforans. I. Infection of host cells. Can J Bot 58:1280-1290

Raghukumar C (1980b) An ultrastructural study of the marine diatom Licmophora hyalina and its parasite Ectrogella perforans. II. Development of the fungus in its host. Can J Bot 58:2557-2574

Raven JA, Waite AM (2004) The evolution of silicification in diatoms: inescapable sinking and sinking as escape? New Phytol 162:45-61

Ronquist F, Teslenko M, van der Mark P, Ayres DL, Darling A, Höhna S, Larget B, Liu L, Suchard MA, Huelsenbeck JP (2012) MrBayes 3.2: efficient Bayesian phylogenetic inference and model choice across a large model space. Syst Biol 61:539-542

Scherffel A (1925) Endophytische Phycomyceten-Parasiten der Bacillariaceen und einige neue Monadinen. Ein Beitrag zur Phylogenie der Oomyceten (Schroter). Arch Protistenkd 52:1-141

Schnepf E, Drebes G (1977) Über die Entwicklung des marinen parasitischen Phycomyceten Lagenisma coscinodisci (Lagenidiales). Helgoländer Meeresun 29:291-301
Schnepf E, Kühn SF, Bulman S (2000) Phagomyxa bellerocheae sp. nov. and Phagomyxa odontellae sp. nov., Plasmodiophoromycetes feeding on marine diatoms. Helgol Mar Res 54:237-251

Scholz B, Küpper FC, Vyverman W, Karsten U (2015) Effects of eukaryotic pathogens (Chytridiomycota and Oomycota) on marine benthic diatom communities in the Solthörn tidal flat (southern North Sea, Germany). Eur J Phycol 51:253-269

Skovgaard A (2014) Dirty tricks in the plankton: diversity and role of marine parasitic protists. Acta Protozool 53:51-62

Sparrow FK (1936) Biological observations on the marine fungi of woods hole waters. Biol Bull 70:236-263

Sparrow FK (1960) Aquatic phycomycetes. The University of Michigan Press, USA

Stamatakis A (2014) RAxML version 8: a tool for phylogenetic analysis and post-analysis of large phylogenies. Bioinf 30:1312-1313

Tamura K, Peterson D, Peterson N, Stecher G, Nei M, Kumar S (2011) MEGA5: molecular evolutionary genetic analysis using maximum likelihood, evolutionary distance, and maximum parsimony methods. Mol Biol Evol 28:2731-2739

Thines M (2019) An evolutionary framework for host shifts-jumping ships for survival. New Phytol 224:605-617

Thines M, Kamoun S (2010) Oomycete-plant coevolution: recent advances and future prospects. Curr Opin Plant Biol 13:427-433

Thines M, Nam B, Nigrelli L, Beakes G, Kraberg A (2015) The diatom parasite Lagenisma coscinodisci (Lagenismatales, Oomycota) is an early diverging lineage of the Saprolegniomycetes. Mycol Prog 14: 75

Thornton DCO (2002) Individuals, clones or groups? Phytoplankton behaviour and units of selection. Ethol Ecol Evol 14:165-173

Vallet M, Baumeister TUH, Kaftan F, Grabe V, Buaya A, Thines M, Svatoš A, Pohnert G (2019) The oomycete Lagenisma coscinodisci hijacks host alkaloid synthesis during infection of a marine diatom. Nat Commun 10:4938

Wang Y, Tian RM, Gao ZM, Bougouffa S, Qian PY (2014) Optimal eukaryotic $18 \mathrm{~S}$ and universal $16 \mathrm{~S} / 18 \mathrm{~S}$ ribosomal RNA primers and their application in a study of symbiosis. PLoS One 9:e90053

Zhang S, Liu H, Ke Y, Li B (2017) Effect of the silica content of diatoms on protozoan grazing. Front Mar Sci 4:1-10

Zopf W (1884) Zur Kenntniss der Phycomyceten. I. Zur Morphologie und Biologie der Ancylisteen und Chytridiaceen. Nova Acta Academiae Caesareae Leopoldino-Carolinae Germanicae Naturae Curiosorum 47:143-236

Publisher's note Springer Nature remains neutral with regard to jurisdictional claims in published maps and institutional affiliations. 